\title{
Optimization with excess electricity management of a PV, energy storage and diesel generator hybrid system using HOMER Pro software
}

\author{
Aysar Yasin, Mohammed Alsayed \\ Department of Energy and Environmental Engineering, An-Najah National University, Palestine
}

\begin{tabular}{l}
\hline Article Info \\
\hline Article history: \\
Received Jan 5, 2020 \\
Revised Feb 19, 2020 \\
Accepted Mar 3, 2020 \\
\hline
\end{tabular}

\section{Keywords:}

HOMER Pro

Hybrid energy systems

Optimization

Palestinian territories

Stand-alone power systems

\begin{abstract}
A standalone microgrid power system is proposed to electrify a small agricultural community in Palestinian territories. The load includes residential and water pumping. The community comprises about 30 households with some service buildings in addition to the water pumping system. The average load energy demand is $300 \mathrm{kWh} /$ day and the average power demand is $12.5 \mathrm{~kW}$. The average energy demand for water pumping is $49 \mathrm{kWh} /$ day. The region has abundant solar radiation potential with a daily average of $5.6 \mathrm{kWh} / \mathrm{m}^{2}$. The optimum design was achieved using HOMERPro software. It took into consideration real solar radiation, electrical demand profile for the community and water pumping, and market cost of all equipment. The results showed that the best hybrid system among all feasible configurations is a PV with energy storage combined with a diesel generator. The net present cost of the system is USD 636,150 and the cost of energy (COE) produced is USD $0.438 / \mathrm{kWh}$. Sensitivity analysis is considered to study the impact of variations in PV cost, diesel fuel price, and maximum annual capacity shortages (MACS), the results showed that MACS has no effects. Energy management procedure is followed to reduce the excess electricity from $10.6 \%$ to $6.24 \%$. This reduces COE from 0.438 to USD $0.416 / \mathrm{kWh}$.
\end{abstract}

This is an open access article under the CC BY-SA license.

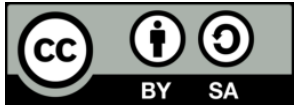

\section{Corresponding Author:}

Aysar Yasin,

Department of Energy and Environmental Engineering,

An-Najah National University,

Omar Ibn Al-Khattab St., PO Box 7, Nablus, Nablus, Palestine.

Email: aysar.yasin@najah.edu

\section{INTRODUCTION}

As a result of global population growth, and humans continual living quality improvement. Energy demand grows rapidly which created many supply, environmental, economic, and social challenges. Like other countries, Palestinian territories (PA) face similar burdens. According to the Palestinian Central Bureau of Statistics (PCBS), PA imported 5,576,864 MWh of electricity in 2017 (4,801,564 MWh for the West Bank (WB), and 775,300 MWh for Gaza strip) [1]. PA depends almost completely on imported electricity, where about $90 \%$ of consumed electricity in 2017 was imported. This dependency is almost on Israeli sources. Only small fraction of electric demand is fulfilled from the Gaza power plant or imported from Jordan and Egypt [2]. This dependency will continue at least for the next decade.

Figure 1 illustrates PA dependency percentage on imported electricity. However, due to different economic conditions and political issues complexities, PA suffers from high energy prices fluctuations; as a result of high electrical tariff rates imposed by the Israeli electrical company (IEC). Moreover, it suffers from an electricity shortage in many locations. PA energy balance shows that electrical energy constitutes about $31 \%$ of the total energy consumed. The available electricity is insufficient to fulfill local community 
needs. The problem becomes worse year after year, especially when taking into consideration that the annual demand growth equals $7 \%$.

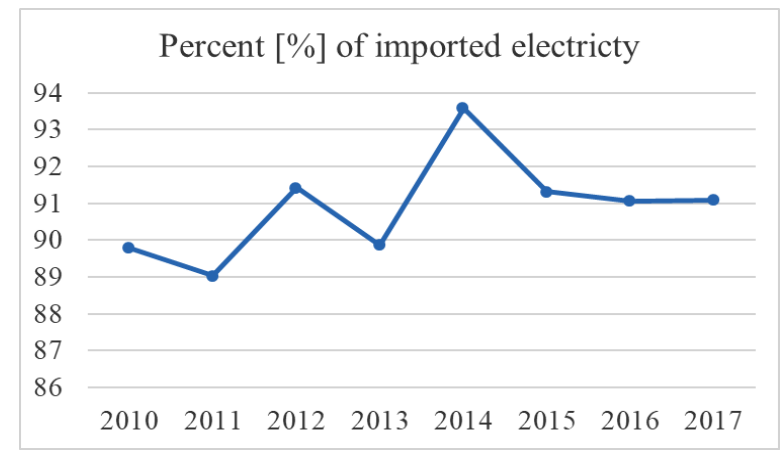

Figure 1. PA percentage of imported electricity (2010-2017) [1]

Under these circumstances, many Palestinian small communities and/or villages are obliged to use small diesel generators (DG) to partially cover their electrical energy demand. Most of these communities and villages are isolated and far away from the electric grid, which makes their connection very expensive and requires grid expansion. Due to high diesel fuel prices, DG operating hours are limited to small periods of time. Figure 2 illustrates diesel fuel price fluctuations in the year 2017. On the other hand, domestic size DG cost is quite affordable, around $\$ 800$ per unit (less than $5 \mathrm{~kW}$ ). However, historical data shows that diesel fuel price is continuously increasing. DGs need maintenance to follow up due to its frequent faults, and it contributes to increasing local air pollution. And so, DGs are ineffective for rural electrification.

Palestinian Energy and Natural Resources Authority (PENRA) focused on solving energy sector dependency, high prices, and environmental consequences by promoting photovoltaic (PV) and wind turbine (WT) energy generators. Palestine has high solar radiation potential and a relatively high number of sunshine hours (3000 hours per year). Its average horizontal solar radiation equals $5.6 \mathrm{kWh} / \mathrm{m}^{2} / \mathrm{day}$ [3]. During the last two decades, PV proved itself as a feasible and reliable technology. In contrast, WT potential is still fuzzy. The average wind speed is generally low. WT can be economically competitive due to increasing diesel fuel price which continually pushes DG to become the unfeasible solution. However, for the sake of accuracy and practicality, WT was not considered in this research.

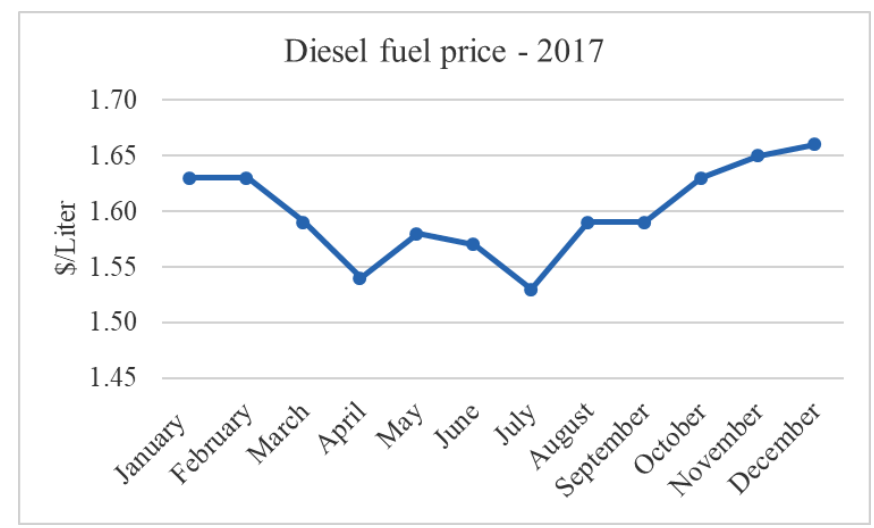

Figure 2. Diesel fuel price fluctuation through 2017 [1]

Due to renewable energy sources (RES) intermittency. Neither PV nor WT can be used independently to fulfill electric load. RES intermittency is a result of weather seasonal and daily variation and stochastic nature. Solar radiation, atmospheric temperature, and wind speed are variable, and most of the time, very difficult and unfeasible to predict. So, utilizing such systems in a stand-alone configuration needs energy storage system (ESS) and/or another controllable back-up system such as DG. Such configuration is called a hybrid power generation system. Generally, hybrid power generation systems integrate RES with other 
sources such as DG and/or ESS to meet energy needs for a specific load [4, 5]. Hybrid power generators improve system overall reliability while using ESS to reduce reliance on one unique energy source [6-9]. This paper investigates the technical and economic feasibility of using a standalone hybrid system based on PV accompanied by DG and/or ESS to supply the electrical demand for an isolated small Palestinian village in Tubas governorate. It is known that ESS systems are technically efficient when it comes to excess energy management, however, it raises investment value to unfeasible limits. This research proposed a suitable compromise for this issue as well. Figure 3 describes the schematic diagram of the considered system.

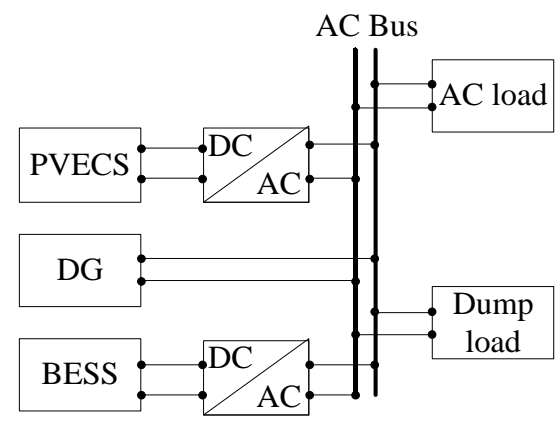

Figure 3. Schematic of the proposed standalone hybrid system

The proposed system design is quite challenging. Many factors play a role in determining the optimum system components size. For example, solar energy intermittent nature, system components costs, demand variability, and system intended availability are the most important. Other factors are related to system uncertainty such as energy sources cost. Many available software tools are capable of solving such complexities. Among many alternatives, HOMER software is considered in this research. It is a well-known tool in sizing hybrid RE systems.

There are many research articles discussed the hybrid system optimization for a standalone systems based on RES using HOMER software [10-14]. In [10] performed a techno-economic and environmental feasibility of installing a PV system for a household in Baghdad, Iraq. The system design took into consideration the on-grid and off-grid scenarios. Results revealed that the most economical configuration achieved when allowing the grid to charge batteries. Moreover, adding DG has enhanced system economic feasibility by reducing net present value (NPV) to about $11.6 \%$, but increased $\mathrm{CO}_{2}$ emissions by $32.7 \%$. In paper [11] the authors investigated PV/WT/ESS system configuration optimal feasibility. The system consists of $80 \mathrm{~kW} \mathrm{PV}, 10 \mathrm{~kW} \mathrm{WT}, 300 \mathrm{~kW}$ of ESS and $30 \mathrm{~kW}$ inventor. Achieved results show that COE is varying from $1.001 \$ / \mathrm{kWh}$ in a $0 \%$ capacity shortage to $0.619 \$ / \mathrm{kWh}$ in a $5 \%$ capacity shortage.

In paper [12] the authors performed a techno-economic feasibility study to meet the electrical energy demand of vacation homes in Izmir, Turkey. PV/WT/ ESS/fuel cell off-grid systems were considered. Results revealed batteries are still more feasible than fuel cells. In [13] analyzed the techno-economic feasibility of a hybrid DG/WT/ESS power system. Different types of batteries for a small residential area (280 homes) located in Gansu Province in China were considered. Results indicate that DG/lithium-ion battery is the most environment-friendly system. Selecting suitable WT can improve the comprehensive economic and environmental performance of the system. The authors in [14] investigated the technical and economic feasibility of a hybrid system (PV/DG) in a school located in Algeria to minimize cost by selecting the optimal configuration.

In the following research articles [15-19] further optimization studies were done. Paper [15] defined economic and optimized design of PV/biomass system for an agricultural farm and residential community in the province of Pinjab, Pakistan. NPV and COE results were refined by performing sensitivity analysis. It took biomass potential, biomass price, solar radiation, and load variability into consideration. Author [16] presented a hybrid generation system design using a modified electric system cascade analysis method. PV/WT/ESS were considered, where MATLAB/Simulink model was used for simulation, and results were validated using HOMER.

The researchers in [17] studied the technical, economic, and environmental performance of PV/DG/system convertor/ESS decentralized hybrid systems in Sabah, Malaysia. Different PV penetration levels were considered to determine the impact of PV integration. NPV and LCOE were minimized, and sensitivity analysis was performed. Results showed that PV/DG/ESS has the best technical performance, while also showed good economic and environmental performance. In [18] an economic feasibility analysis

Optimization with excess electricity management of a PV, energy storage and diesel... (Aysar Yasin) 
of a grid-connected PV/WT system for a typical home in Dubai, United Arab Emirates is conducted. COE was calculated under different assumed conditions, including electricity cost and interest rate. Results show that above 8\% annual interest rate, the proposed system lost its feasibility. The authors in [19] modeled and simulated a stand-alone PV $(6.75 \mathrm{~kW})$ supported with 800 Ah battery for on-campus night street light electrification application. Results revealed that connected the system with a grid and incorporating a bi-directional converter will enhance system feasibility.

In the same context, the authors in [20-22] performed different optimization studies. In [20] the authors used a similar approach to design a hybrid system for the educational institution based on biomass gasifier/PV/fuel cell/ESS. In [21] an optimized study is performed to design a stand-alone PV/DG/ESS hybrid alternating current/direct current microgrid residential system, located on an island without the possibility of grid connection. Multi-objective function was considered, for cost and $\mathrm{CO}_{2}$ emissions. Authors in [22] investigated the feasibility of using hybrid PV/WT/ESS systems for supplying the demand of a household. Results showed that WT/fuel cell/battery is the most economical configuration, which had an LCOE equals to US \$0.783/kWh.

Using a similar approach, the authors in [23] performed a cost to benefit accompanied by technical analysis for rural electrification solutions in the southern area of India. Results revealed the feasibility of PV/WT/hydro/battery hybrid power generation system. In [24] a hybrid PV/WT/DG/ESS power generation system for a remote area in the western region of Abu Dhabi was designed, modeled and simulated to fulfill different considered loads. Results revealed that $15 \% \mathrm{PV}$ and $30 \% \mathrm{WT}$ penetration is the most feasible system for $500 \mathrm{~kW}$ average load. In [25] different biomass gasifier microgrid power generation configurations were compared using HOMER software.

In [26] a study is conducted to perform a feasibility study to investigate the performance of a gridconnected PV system to supply the demand of a dairy farm in the north of Algeria. In [27], a hybrid PV/WT off-grid system feasibility to electrify an isolated area of China was investigated. Results showed that COE is US $\$ 0.595 / \mathrm{kWh}$. Authors in [28] evaluate the techno-economic and environmental benefits of PV/BESS in a farmhouse using HOMER, the study found that a standalone PV/BESS has higher economic viability when compared to DG counterparts in terms of the total net present cost. The authors in [29] found that an off-grid hybrid system based on RES obtains lower COE when compared with PV or wind energy system works individually. The study is performed utilizing HOMER software.

The main problem encountered with the standalone system is the generated excess power. The reviewed papers concentrate on technical and economic aspects without managing excess power. This article in addition to investigating the techno-economic feasibility of the proposed system finds a feasible solution to the excess power generation that benefited from the nature of the load. This is considered a novelty of this paper.

\section{HOMER PRO SOFTWARE}

As mentioned before, designing microgrid renewable energy systems is quite complicated. HOMER Pro software is capable to solve such problems efficiently, aiming for an optimal solution enhanced by sensitivity analysis. HOMER stands for a hybrid optimization model for electric renewable [30, 31]. HOMER economic analysis is based on a life cycle cost approach when calculating NPV. Which is more appropriate and realistic when it comes to systems comparison. Simply, NPV is calculated using (1).

$$
N P V=\text { Initial Cost }+ \text { Annual cost }\left(\frac{(1+i)^{N}-1}{i(1+i)^{N}}\right)
$$

HOMER analysis provides some valuable performance indicators. Among many, the levelized cost of energy (COE) in $\$ / \mathrm{kWh}$ is with great value for comparison. Especially with other alternatives, other energy sources. COE can be calculated using (2).

$$
C O E=\frac{N P V\left(\frac{i(1+i)^{N}}{(1+i)^{N}-1}\right)}{E_{l}+E_{\text {def }}+E_{\text {grid }}}
$$

where $E_{1}$ and $E_{\text {def }}$ are the total amounts of primary and deferrable load, respectively. $E_{\text {grid }}$ is the annual amount of electricity sold to the grid. HOMER simulates different configurations of the hybrid system during the optimization process. The optimal solution is defined as the configuration that provides minimum NPV [32]. 


\section{SITE DESCRIPTION, LOAD DEMAND, AND HYBRID SYSTEM RESOURCES}

\subsection{Site description and load demand}

Ein Albaida village is located $15 \mathrm{~km}$ north of Tubas district in the northeastern part of the West Bank. It is bordered by the Jordan River to the east. The total area of Ein Albaida village is 15,000 dunums. 480 dunums are classified as built-up areas, whilst 8,500 dunums are agricultural areas cultivated in deferent crops [33]. The proposed system will electrify part of the residential load of the village and operate a water pump. The selected community includes about 25 households in addition to service buildings. The average energy demand of the residential load is shown in Figure 4, each season has its consistent load profile. The average load energy demand is $300 \mathrm{kWh} /$ day and the average power demand is $12.5 \mathrm{~kW}$. The average load factor is 0.284 .
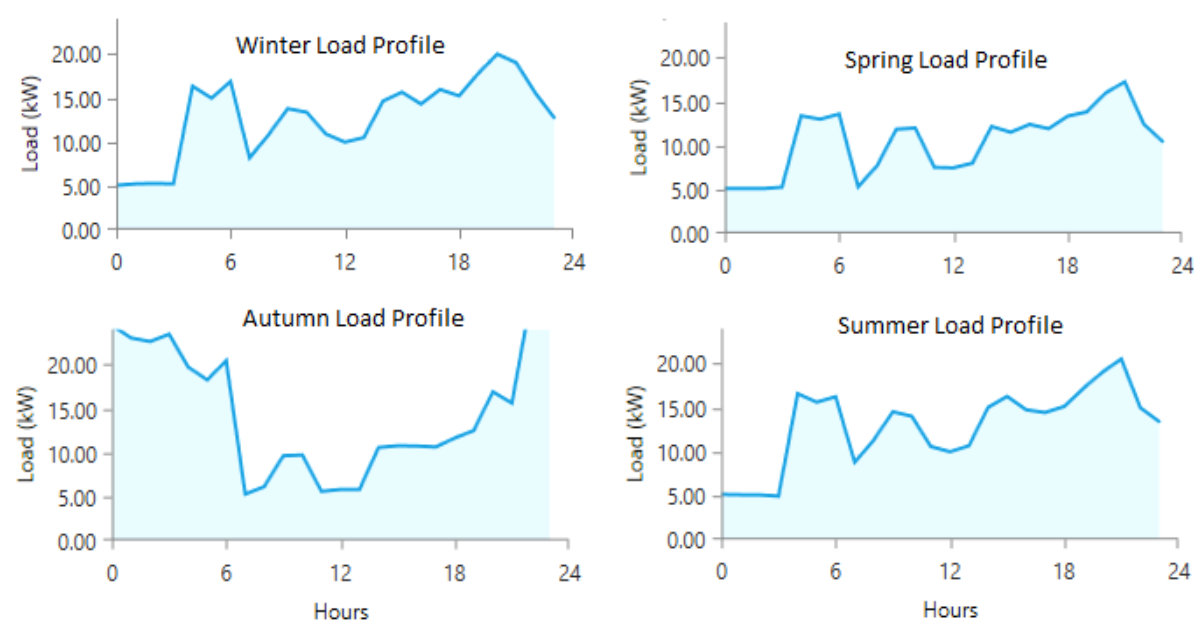

Figure 4. Average load profile of the community residential load

The water pumping load is shown in Figure 5, two load profiles are observed according to farmers' inputs. Figure 5 (a) shows the load profile from the first of March until the end of October, in this profile, the load starts up from 8:00 until 16:00. Figure 5 (b) shows the profile from the day of November until the end of February, in this profile, the load starts up from 9:00 until 15:00.

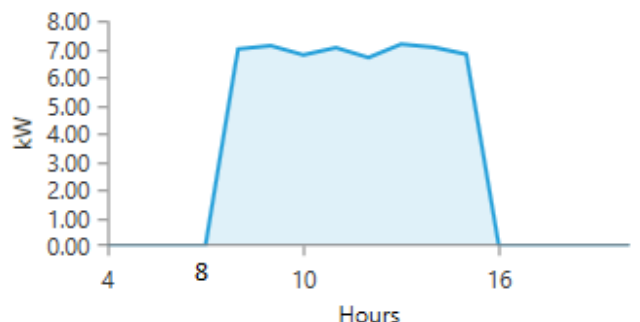

(a)

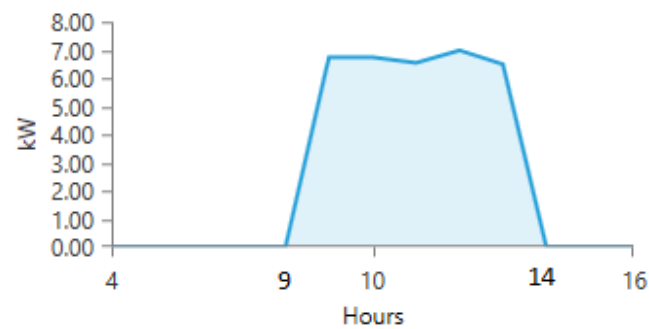

(b)

Figure 5. Average load profile of the water pumping system, (a) Load profile in March-October,

(b) Load profile in March November-February

\subsection{Solar radiations profile}

Palestinian territories have sufficient solar radiation potential to utilize solar electricity especially PV energy, the daily average of solar radiation on the horizontal surface was measured to be $5.45 \mathrm{kWh} / \mathrm{m}^{2}$ day [34-36]. Figure 6 shows the monthly average daily solar radiation input data of the selected site to HOMER software which in role generates synthetic 8760-hour total solar radiation data set utilizing special procedure. The monthly global daily solar radiation on the horizontal surface of Tubas governorate is presented in Figure $6[35,37]$. Ambient air temperature is also important in estimating potential PV output. Figure 7 shows that during the day the hourly average temperature is ranging from 20 to $27^{\circ} \mathrm{C}$. 


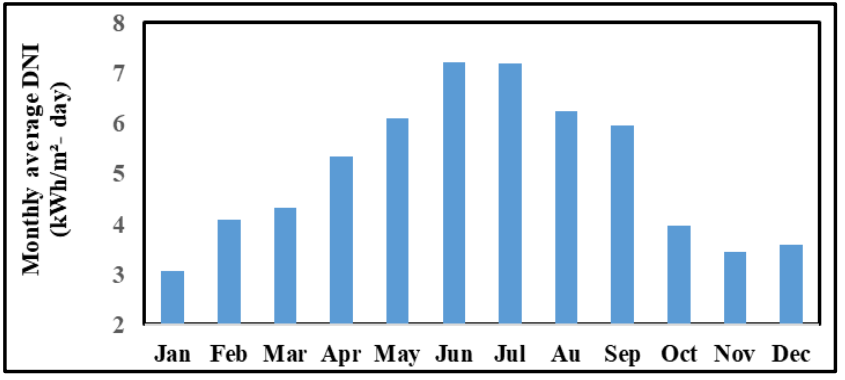

Figure 6. Monthly average global daily solar radiation on a horizontal surface

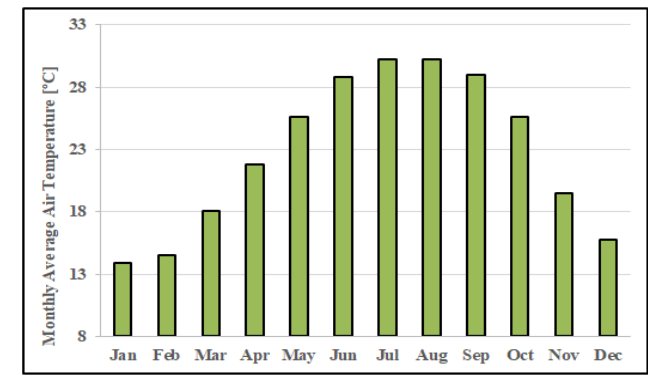

Figure 7. Monthly average air temperature [34]

\subsection{Wind speed profile}

The potential of wind energy in Palestinian territories is not assessed in all locations especially the site under investigation, it is located near the Israeli military region which means installing measurement stations and wind turbines are forbidden. In general, the potential of wind energy in the Palestinian territories is limited [38]. In this case study, wind energy is not considered.

\subsection{Diesel fuel}

The density of the diesel fuel considered in this study is $820 \mathrm{~kg} / \mathrm{m}^{3}$, lower heating value $43.2 \mathrm{MJ} / \mathrm{kg}$, carbon content $88 \%$ and sulfur content $0.33 \%$. The average price of diesel fuel in Palestinian territories of this year (2020) is about $1.4 \mathrm{US} \$ / \mathrm{D} / \mathrm{L}$.

\section{PROPOSED CONFIGURATIONS OF HYBRID ENERGY SYSTEM}

The proposed configuration of the hybrid system used in this study is shown in Figure 1 and it consisted of PV, DG and battery energy storage system (BESS). The analysis of such a complicated system is based on HOMER pro software and based on the research methodology shown in Figure 8. The technical specification and cost of each component used in the software are illustrated in detail. The price of each component based on the local prices in Palestinian territories in 2020.

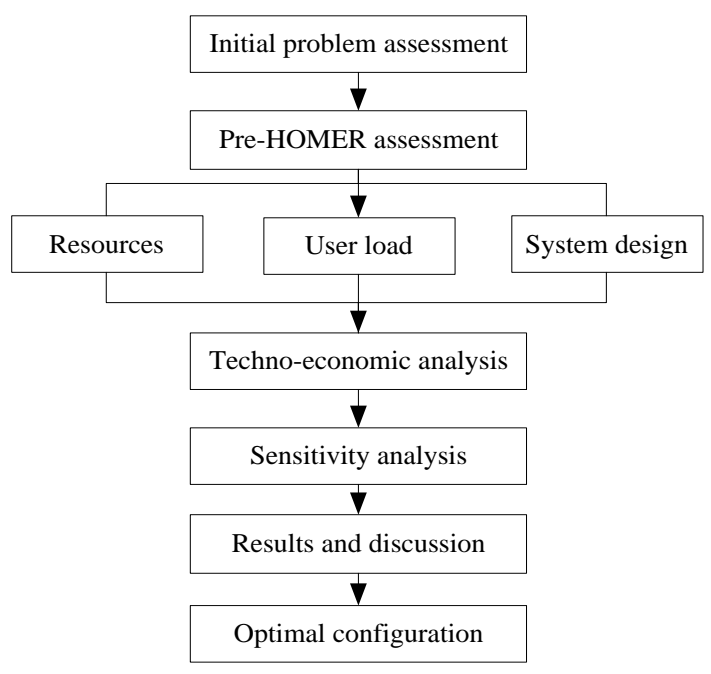

Figure 8. Research methodology

\subsection{Photovoltaic energy conversion systems (PVECS)}

The main data required by the software regarding the PVECS includes The sizes of PV modules considered in the study ranges from 50 to $100 \mathrm{~kW}$ with $2 \mathrm{~kW}$ step size. The capital, replacement and O\&M costs are US $\$ 2000 / \mathrm{kW}$, US $\$ 1750 / \mathrm{kW}$ and US $\$ 20 /$ year, respectively. The lifetime of the PVECS is 20 years. The derating factor is $80 \%$ and the system is fixed without tracking at a slope of $45^{\circ}$ angle and $0^{\circ}$ azimuth angle. 


\subsection{Power converter}

The converter can work as an inverter once converts electric power from DC to AC and the efficiency is assumed $90 \%$ and at the same time, it can work as a rectifier once converts the electric power from AC to DC and the efficiency is assumed $85 \%$. The sizes of power converters considered ranges from 20 to $44 \mathrm{~kW}$. The capital, replacement and O\&M costs are US $\$ 1000 / \mathrm{kW}$, US $\$ 1000 / \mathrm{kW}$ and 4 US $\$ / y e a r$, respectively. The lifetime is 15 years.

\subsection{Diesel generator}

The DG is utilized to cover the lack of power from RES. The sizes of diesel generators considered in the study are $12,14,16,18,20,22,24,26$, and $28 \mathrm{~kW}$. The capital, replacement and O\&M costs are USD $1500 / \mathrm{kW}$, USD $1375 / \mathrm{kW}$ and USD $0.02 / \mathrm{h}$, respectively. The lifetime of the DG is 15000 operating hours. Figure 9 shows the DG efficiency curve and Figure 10 shows the DG fuel consumption curve [39].

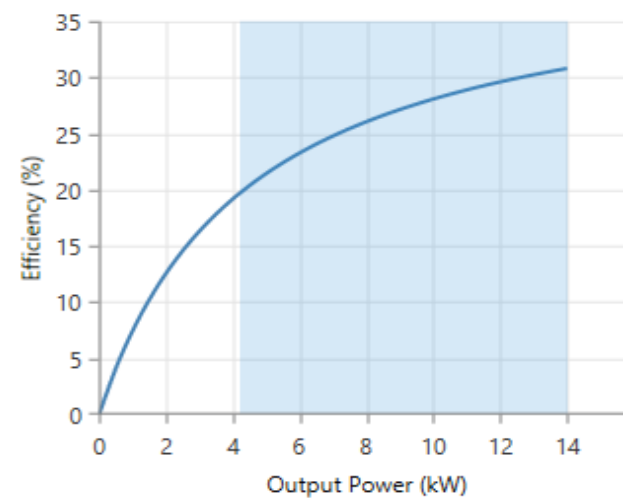

Figure 9. Diesel generator efficiency curve

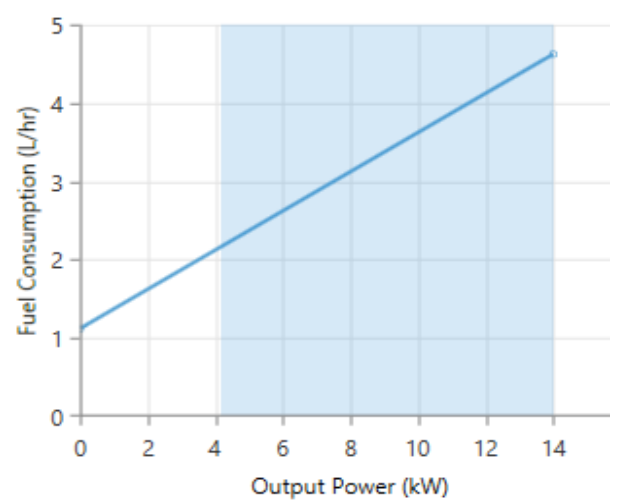

Figure 10. Diesel generator fuel consumption curve

\subsection{Battery energy storage system}

The energy storage system is very important in a standalone system as renewable energy sources are intermittent and stochastic in nature. The physical properties of the battery bank used in the study are the nominal voltage $4 \mathrm{~V}$, nominal capacity $1900 \mathrm{Ah}(7.6 \mathrm{kWh})$, round-trip efficiency $80 \%$, and minimum state of charge $40 \%$. The capacity curve in Figure 11 [38] shows the discharge capacity of the battery in ampere-hours versus the discharge current in amperes. The capital, replacement and O\&M costs of each battery are USD 1100, USD 5000 and USD 10/year, respectively. The lifetime of each unit is 15000 operating hours.

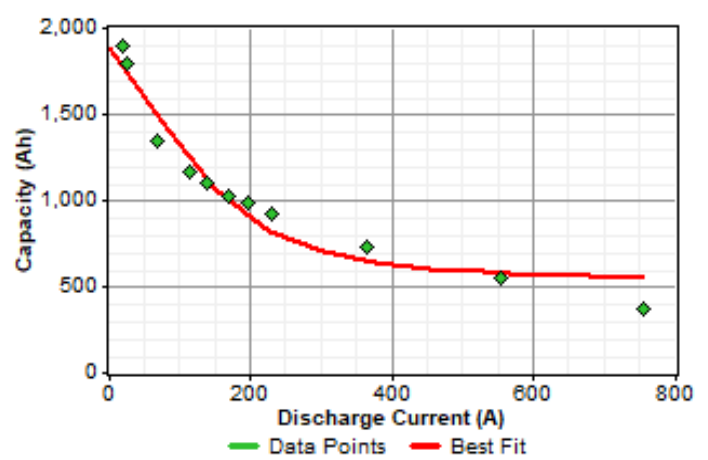

Figure 11. The capacity curve of the BESS

\section{SIMULATION RESULTS AND DISCUSSION}

HOMER pro illustrates optimization results by displaying the lowest-cost configuration within each system category or type, which means the software proposes different types of configurations with different power systems. After performing a large number of simulations, the most feasible configurations appear below: 


\subsection{PV/BESS with DG}

The results of the optimization analysis indicate that the PV power system with BESS combined with DG is the most feasible power system. Figure 12 shows a schematic diagram of the microgrid hybrid power system, it consists of a PV system with $88 \mathrm{~kW}$, DG with $14 \mathrm{~kW}, 144$ batteries, and $38 \mathrm{~kW}$ power converter. The total capital cost is US $\$ 645,622$. The total capital cost consists of the capital cost, replacement cost, O\&M cost and salvage cost as shown in Figure 13. The COE is US $\$ 0.438 / \mathrm{kWh}$. Figure 13 shows that the capital cost of the BESS and PV system have the highest NPC as they encountered high capital costs. The running cost of DG is the highest because of fuel consumption. The converter has the lowest cost. The monthly average electric production is shown in Figure 14. Figure 14 shows that most of the load is fed from the PV power system at a percentage of $87 \%$ while the DG covers about $12 \%$ of the load.

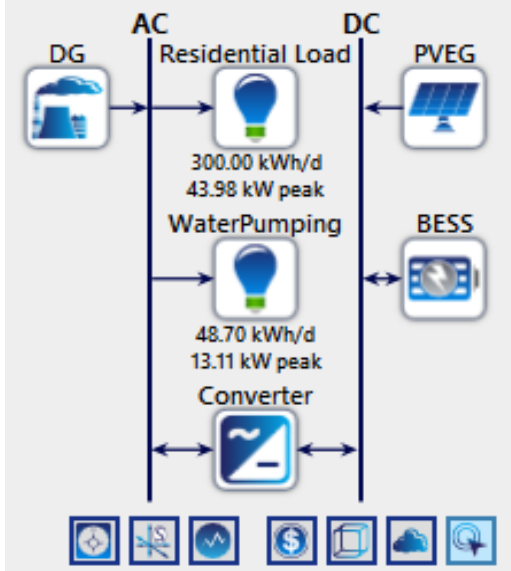

Figure 12. Schematic of PV/BESS combined with DG

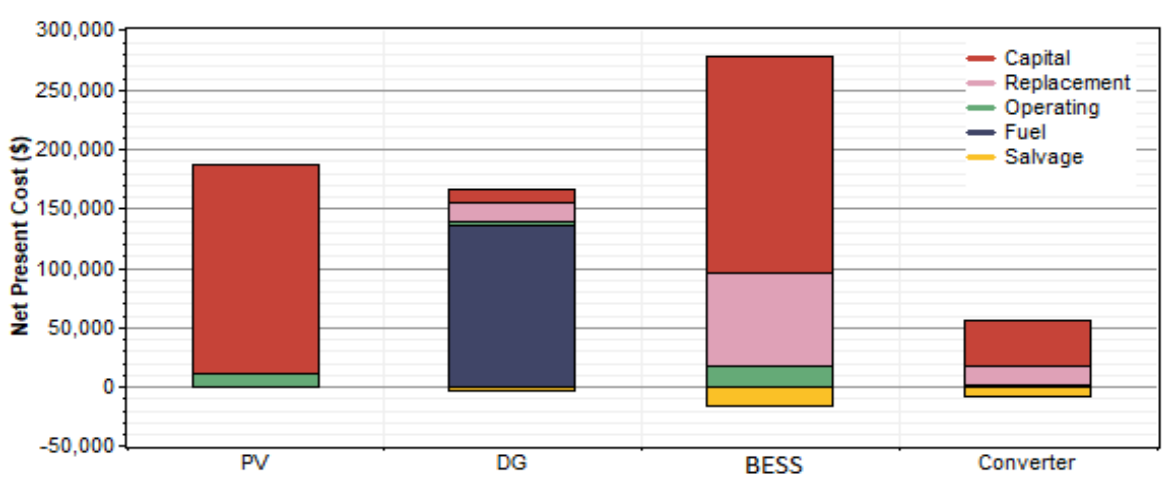

Figure 13. Simulation results: cash flow summary of PV/BESS combined with DG

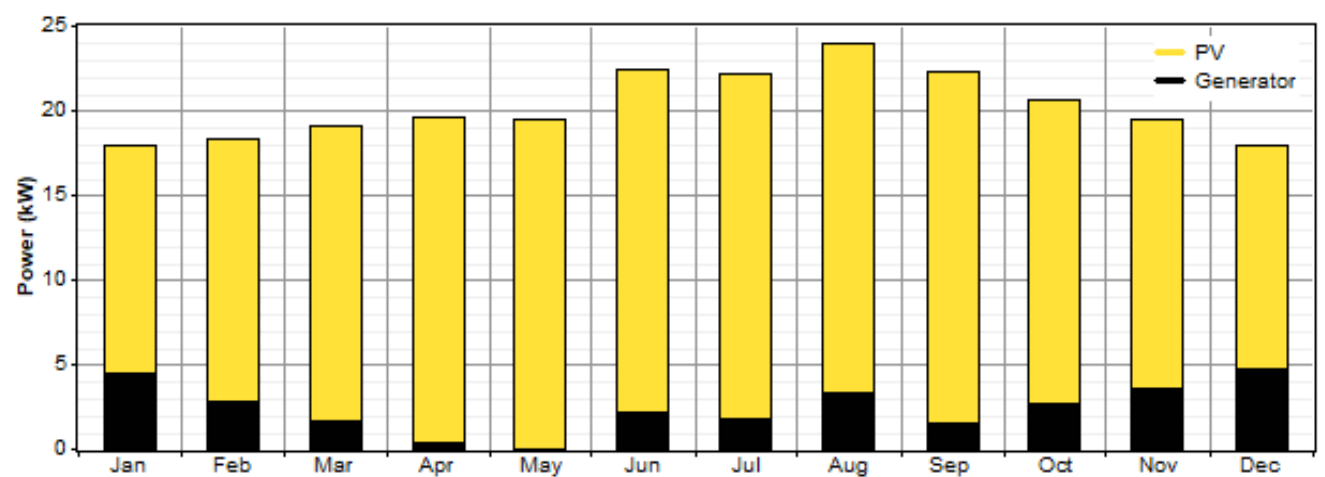

Figure 14. The monthly average electric production for PV/BESS/DG 
The capacity factor of the PV system is $19.8 \%$ and the total annual operation hours are 4391. The mean output per day is $428 \mathrm{kWh}$ and the levelized COE from the PV system is US $\$ 0.0961 / \mathrm{kWh}$. The total annual energy generated from the system is $175 \mathrm{MWh}$ while the annual load is about $127 \mathrm{MWh}$ which means excess energy of about $10.6 \%$. The results show that the unmet electric load is $0.454 \mathrm{MWh} /$ year which is about $0.4 \%$ of the load. The energy production from DG is about $22 \mathrm{MWh} / \mathrm{year}$ which is about $12 \%$ of the total annual energy produced. The number of operational hours is 2285 and the capacity factor is about $17.4 \%$. The hourly fixed generation cost is US\$2.46, the specific diesel consumption is $0.37 \mathrm{~L} / \mathrm{kWh}$ while the annual diesel consumption is $7895 \mathrm{~L}$.

\subsection{PV/BESS}

Figure 15 shows a schematic diagram of the microgrid hybrid power system, it consists of a PV system with $96 \mathrm{~kW}$ and 288 batteries and a $32 \mathrm{~kW}$ power converter. The total capital cost is USD 731,927. Figure 16 shows the cash flow summary of the NPC of the main components of PV/BESS. The COE is USD $0.521 / \mathrm{kWh}$. In such systems, the renewable energy fraction is $100 \%$. The excess electricity is $12.7 \mathrm{MWh} / \mathrm{year}$ which is about $7.6 \%$. The unmet electric load is about $3.7 \%$.

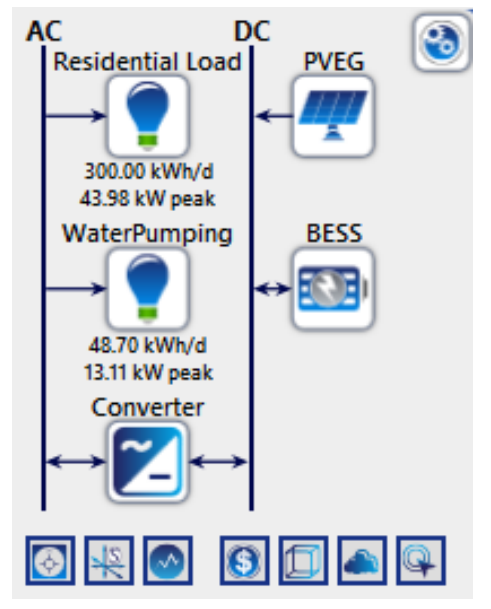

Figure 15. Schematic of PV system combined with BESS

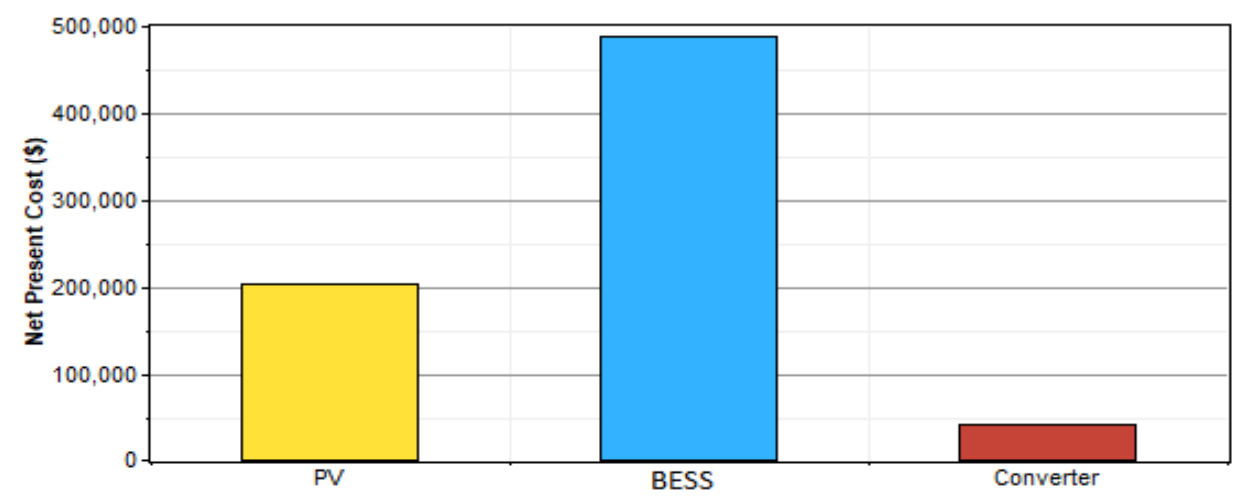

Figure 16. Simulation results: cash flow summary of PV/BESS

\subsection{PV/DG}

Figure 17 shows a schematic diagram of the microgrid hybrid power system consists of a PV system with $65 \mathrm{~kW}$, DG with $25 \mathrm{~kW}$ and $30 \mathrm{~kW}$ power converter. The total capital cost is USD 820,902. Figure 18 shows the cash flow summary of the NPC of the main components of PV/DG. The COE is USD 0.568/kWh. The energy generated from the PV system is $112.928 \mathrm{Mh} /$ year which is about $57 \%$ from the total load, the remains are getting from DG. The excess electricity is $67.174 \mathrm{MWh} /$ year which is about $34 \%$. The unmet electric load is about $1.1 \%$. The monthly average electric production is shown in Figure 19. 


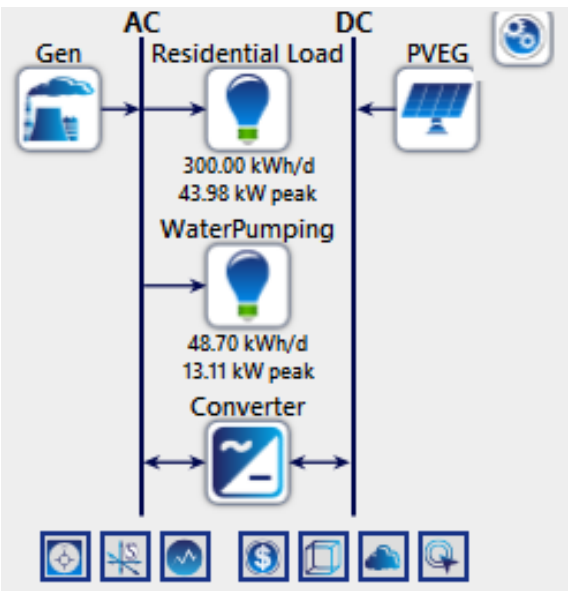

Figure 17. Schematic of PV system combined with DG

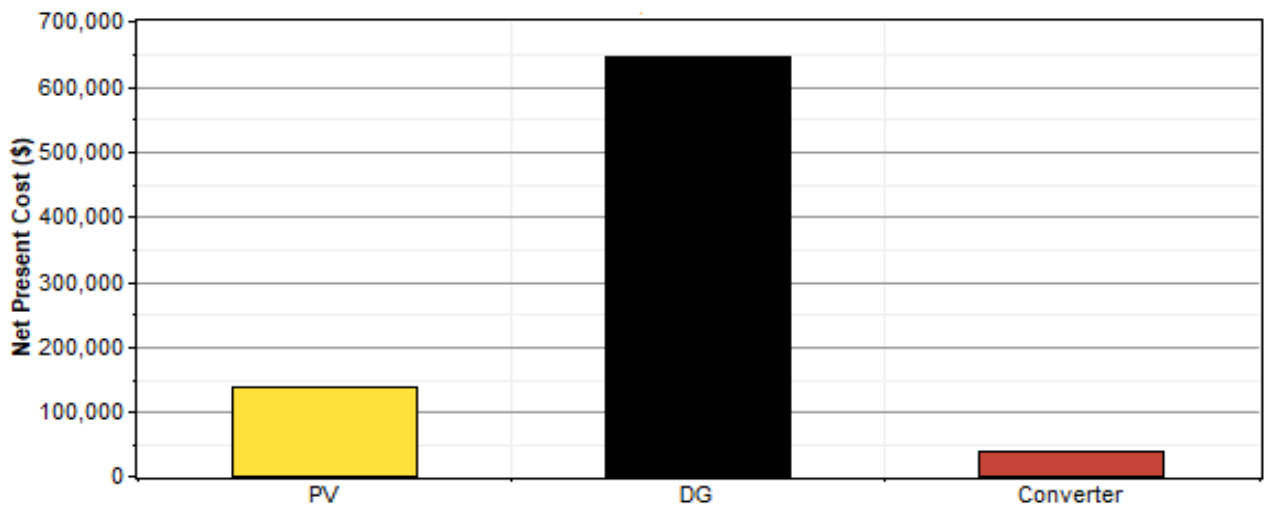

Figure 18. Simulation results: cash flow summary of PV combined with DG

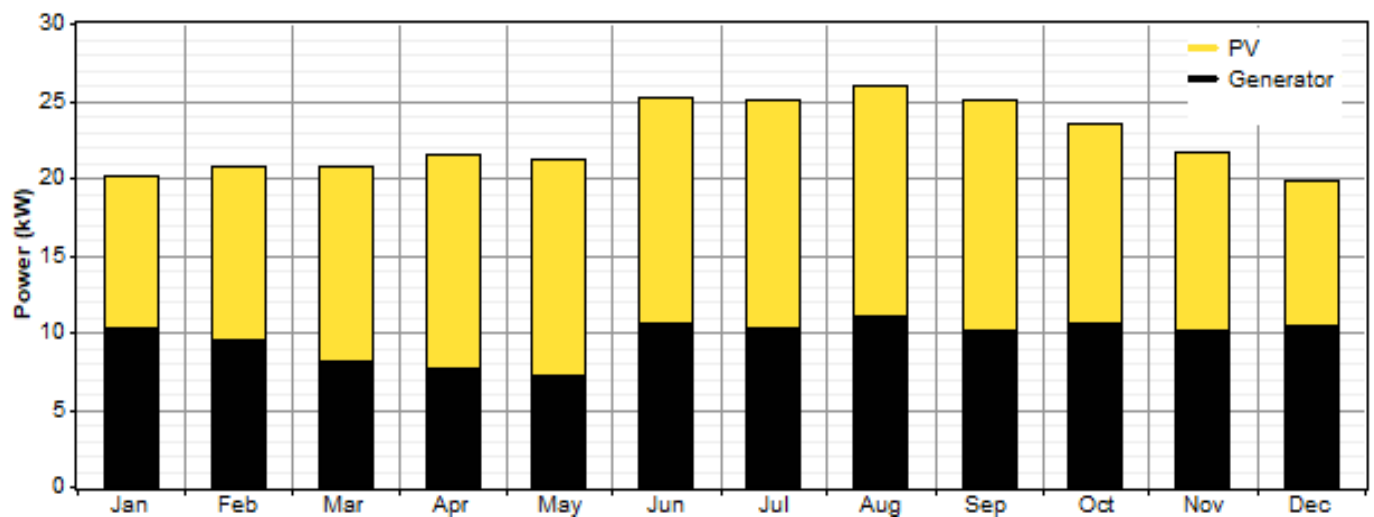

Figure 19. The monthly average electric production for PV/DG

\subsection{Diesel generator}

Figure 20 shows a schematic diagram of a power system consisted only of a $25 \mathrm{~kW}$ DG. The total capital cost is USD 1,069,633. Figure 21 shows the cash flow summary of the NPC of the main components of the system. The COE is USD $0.666 / \mathrm{kWh}$. The energy generated from DG is $128.603 \mathrm{Mh} / \mathrm{year}$ which is a little bit greater than the total load demand. The excess electricity is $2.924 \mathrm{MWh} /$ year which is about $2.3 \%$. The unmet electric load is about $1.25 \%$. The monthly average electric production is shown in Figure 22. 


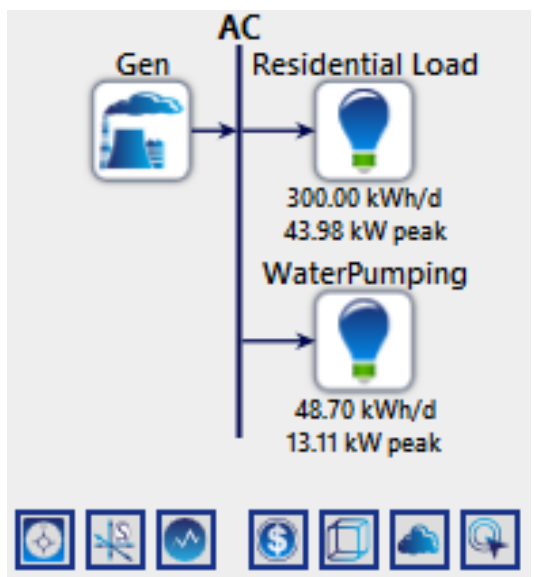

Figure 20. Schematic of power system consisted of DG only

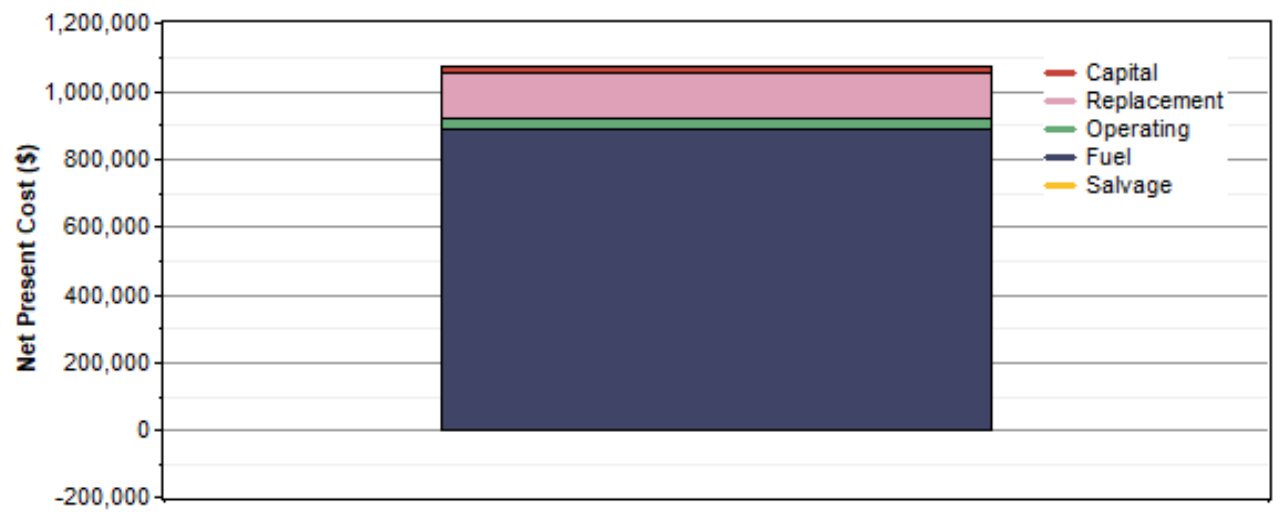

Figure 21. Simulation results: cash flow summary of power system consisted of DG only

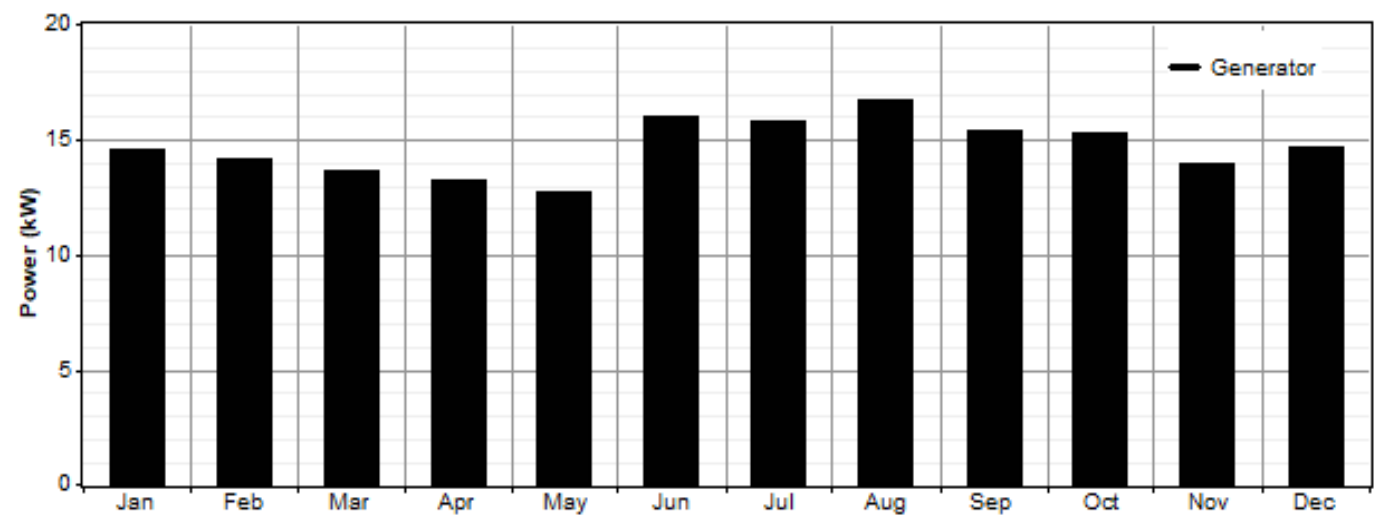

Figure 22. The monthly average electric production for DG only

\subsection{DG/BESS}

Figure 23 shows a schematic diagram of a power system consisted of $17 \mathrm{~kW}$ DG combined with BESS. The BESS consists of 24 batteries. The BESS is connected to the AC bus through a $14 \mathrm{~kW} \mathrm{DC/AC}$ converter. The total capital cost is USD 962,084. Figure 24 shows the cash flow summary of the NPC of the main components of the system. The COE is USD $0.609 / \mathrm{kWh}$. The energy generated from DG is 132.083 $\mathrm{Mh} /$ year with no excess electricity. The unmet electric load is $3.732 \mathrm{Mh} /$ year which is about $3 \%$ from the electric load. The monthly average electric production is shown in Figure 25. 


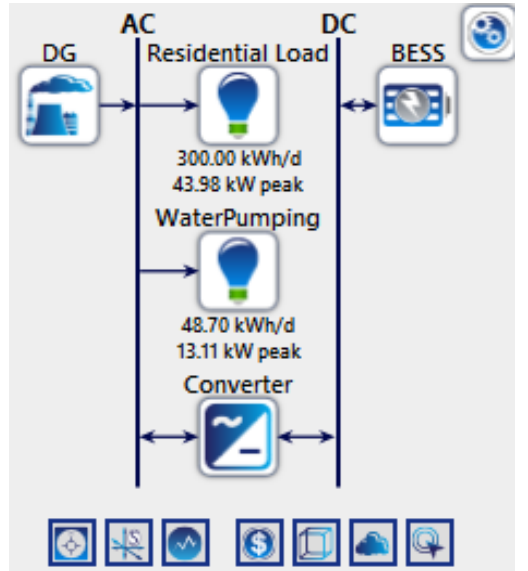

Figure 23. Schematic of power system consisted of DG with BESS

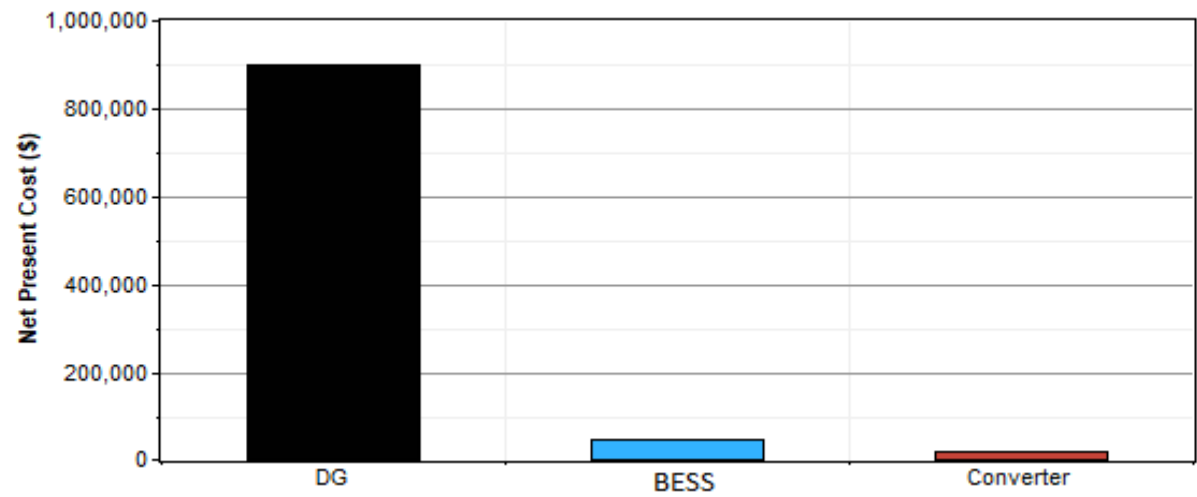

Figure 24. Simulation results: cash flow summary of power system consisted of DG with BESS

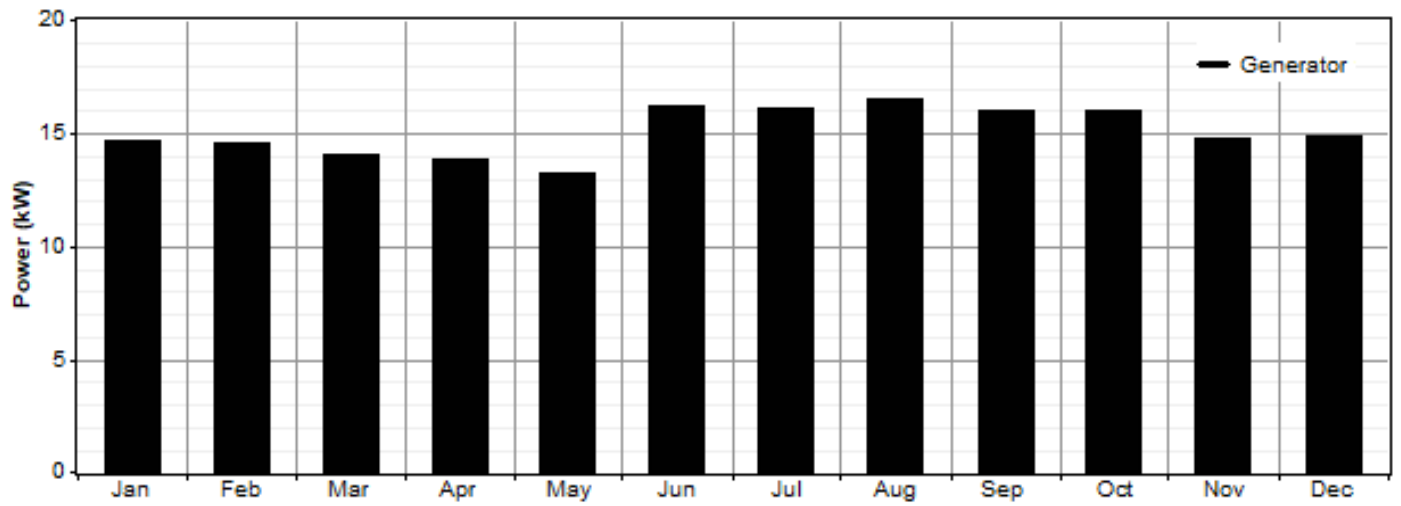

Figure 25. The monthly average electric production for DG/BESS

Table 1 shows a summarization of the simulation results of the five configurations. Figure 26 shows a comparison between the COE for all studied configurations. The lowest COE is obtained from $\mathrm{PV} / \mathrm{BESS} / \mathrm{DG}$ while the second one comes from PV/BESS. The lowest excess electricity is obtained from DG/BESS but this does not chiefly affect the COE. Table 1 shows the amount of air pollution produced in the studied configurations, it revealed that the greatest environmental impact is obtained from the configuration that uses DG only while the least is obtained from utilizing PV/BESS. It is worth noting that the emissions produced from PV/BESS/DG are acceptable compared with other configurations. The results show that the PV/DG, DG/BESS, and DG are not as competitive as they obtained the highest COE. 
Table 1. Environmental impacts of the feasible hybrid system options (kg/year)

\begin{tabular}{|c|c|c|c|c|c|c|}
\hline & & PV/BESS/DG & PV/BESS & $\mathrm{PV} / \mathrm{DG}$ & DG/BESS & DG \\
\hline \multirow[t]{4}{*}{ System sizing } & PV (kW) & 88 & 96 & 65 & - & - \\
\hline & $\mathrm{DG}(\mathrm{kW})$ & 14 & - & 25 & 17 & 40 \\
\hline & BESS (kWh) & 273 & 547 & - & 45 & - \\
\hline & Converter (kW) & 38 & 32 & 30 & 14 & - \\
\hline Electricity & Total electricity & 175,019 & 166,785 & 197,867 & 132,083 & 128,603 \\
\hline production & PV & 152,887 & 166,785 & 112,928 & - & - \\
\hline \multirow[t]{5}{*}{ (kWh/Year) } & DG & 22,132 & - & 84,939 & 132,083 & 128,603 \\
\hline & AC primary load & 126,680 & 122,515 & 125,909 & 123,544 & 125,680 \\
\hline & Unmet load & 596 & 4,760 & 1,366 & 3,732 & 1,596 \\
\hline & Capacity shortage & 862 & 5,782 & 2,769 & 5,556 & 3,421 \\
\hline & Excess electricity & $18,504(10.6 \%)$ & $12,709(7.6 \%)$ & $61,174(34 \%)$ & 0 & $2,924(2.2 \%)$ \\
\hline \multirow[t]{5}{*}{ Economics } & NPV (\$) & 636,150 & 731,927 & 820,902 & 962,084 & $1,069,632$ \\
\hline & $\mathrm{COE}(\$ / \mathrm{kWh})$ & 0.438 & 0.521 & 0.568 & 0.609 & 0.666 \\
\hline & Capital cost $(\$)$ & 390,800 & 555,200 & 180,313 & 55,200 & 20,000 \\
\hline & Operating cost $(\$)$ & 32,074 & 45,513 & 13,401 & 21,143 & 27,992 \\
\hline & Fuel cost $(\$)$ & 130,519 & 0 & 545,693 & 785,364 & 888,907 \\
\hline Emissions & $\mathrm{CO}_{2}$ & 21,404 & 0 & 89,488 & 130,794 & 115,556 \\
\hline \multirow[t]{3}{*}{$\mathrm{kg} /$ year } & $\mathrm{CO}$ & 52.8 & 0 & 221 & 323 & 285 \\
\hline & $\mathrm{SO}_{2}$ & 43 & 0 & 180 & 263 & 232 \\
\hline & $\mathrm{NO}_{2}$ & 471 & 0 & 1,971 & 2881 & 2,545 \\
\hline Total fuel cons. & Diesel (litres) & 8,128 & - & 33,983 & 43,882 & 62,892 \\
\hline BESS & Energy in $(\mathrm{kWh} /$ year $)$ & 88,901 & 95,576 & - & 18,892 & - \\
\hline performance & Energy out (kWh/year) & 71,703 & 77,627 & - & 15,207 & - \\
\hline RE fraction $(\%)$ & & 87 & 100 & 57 & 0 & - \\
\hline
\end{tabular}

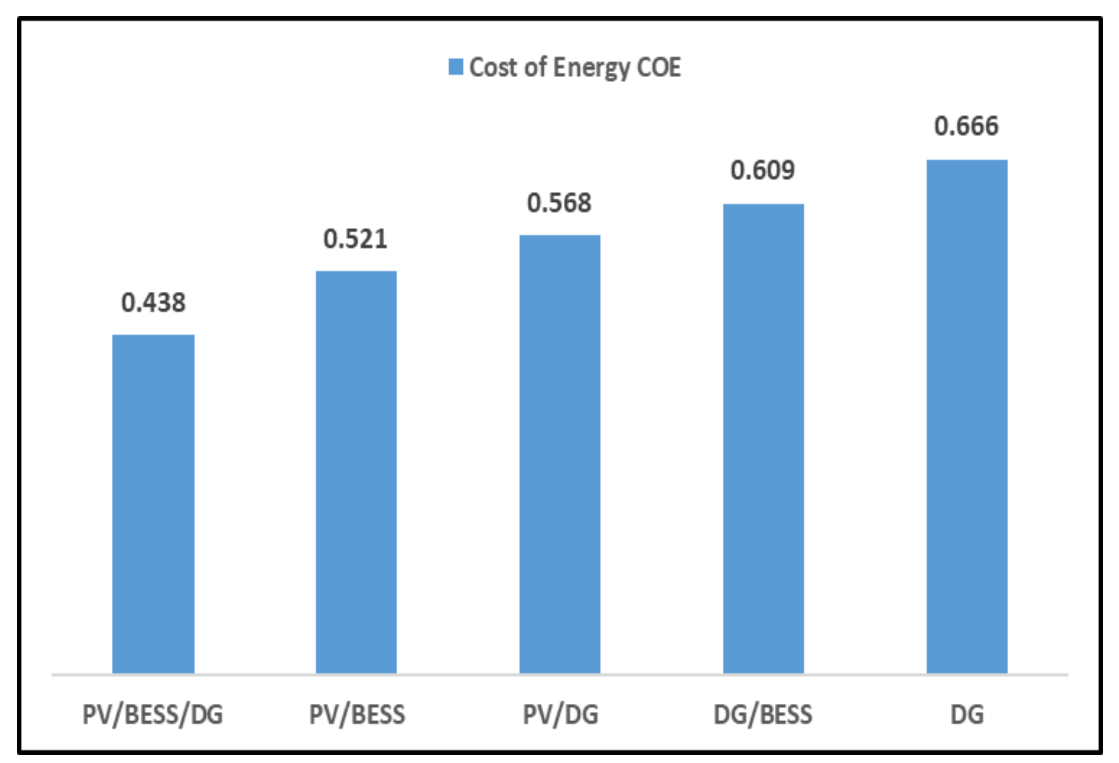

Figure 26. COE for all configurations

\section{SENSITIVITY ANALYSIS}

In order to further understand the effect of each parameter on the $\mathrm{COE}$, it is a good practice to perform sensitivity analysis. The effect of variation in the cost of diesel fuel is mainly examined as this parameter is normally monthly varied. The effect of maximum annual capacity shortage (MACS) is examined. According to historical data of Palestinian territories, the solar radiation is mostly constant and consequently not subjected to sensitivity analysis [34].

Figure 27 shows the impact of PV system cost and the cost of diesel on the COE (US\$/kWh). The sensitivity analysis in Figure 27 shows that the lowest Levelized COE is US $\$ 0.422 / \mathrm{kWh}$ at $0.90 \mathrm{PV}$ capital cost multiplier and fuel price of USD 1.35/L using PVECS/BESS/DG. The COE increases as the price of fuel and PV system increases. The simulation results revealed that the percentage of MACS has no effect on the COE for this case. 


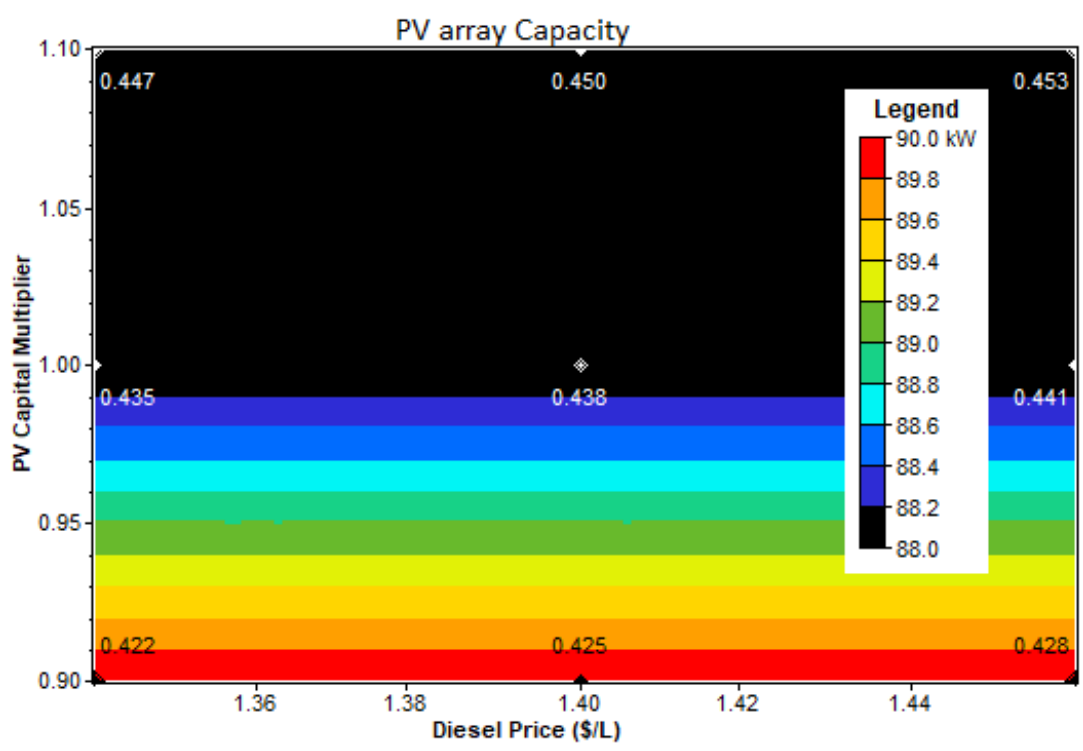

Figure 27. Impacts of PV capital cost and cost of fuel on the COE (US\$/kWh)

\section{MANAGEMENT OF EXCESS ELECTRICAL ENERGY}

The problem of excess electrical energy is serious in a stand-alone system, Figure 28 shows the amount of excess electrical energy obtained in this study for all configurations. In order to utilize the excess electrical energy and consequently reduce the COE, the study proposes an energy management procedure. The surplus electrical energy can be used to pump water in a tank provided that this case study includes water pumping load with tanks. This procedure will be applied only to PV/BESS/DG as it is the best in terms of $\mathrm{COE}$.

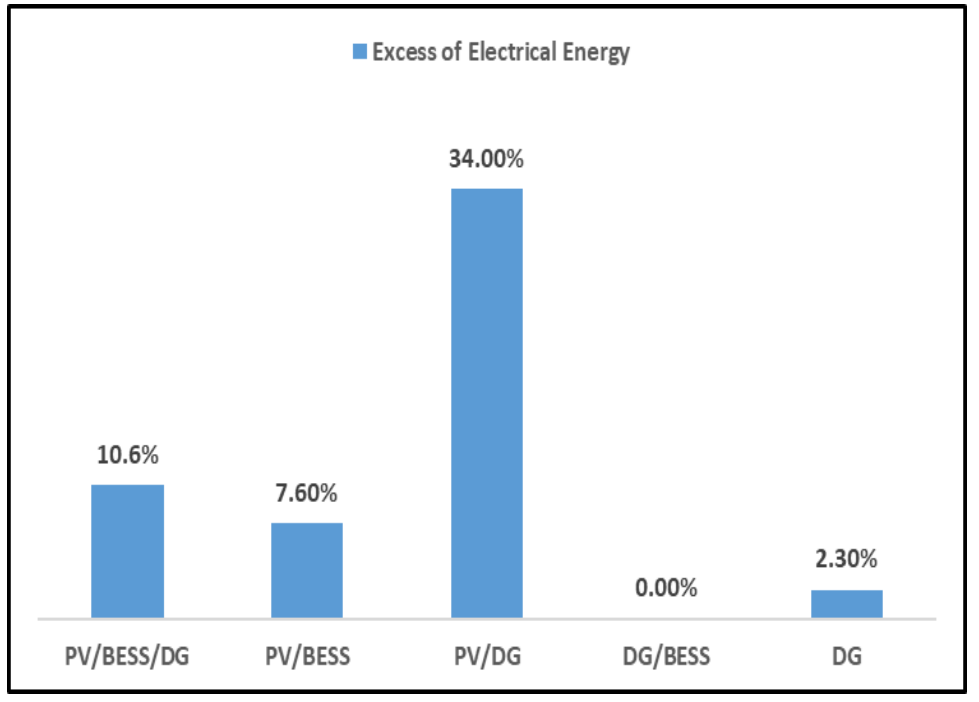

Figure 28. Amount of electrical excess energy in all configurations

In order to manage the excess electrical energy, it is good practice to study the distribution of average excess electrical energy during the day in each month all over the year as shown in Figure 29. It is clear from Figure 29 that the excess electrical energy is not constant during the day. The maximum excess energy has occurred in May and April. It is worth noting that the lower excess energy has occurred in December, January, and February. The maximum excess electrical energy has occurred during the months at low rainfalls. This gives an opportunity to utilize part of the excess energy for water pumping or store energy in the form of mechanical energy. 


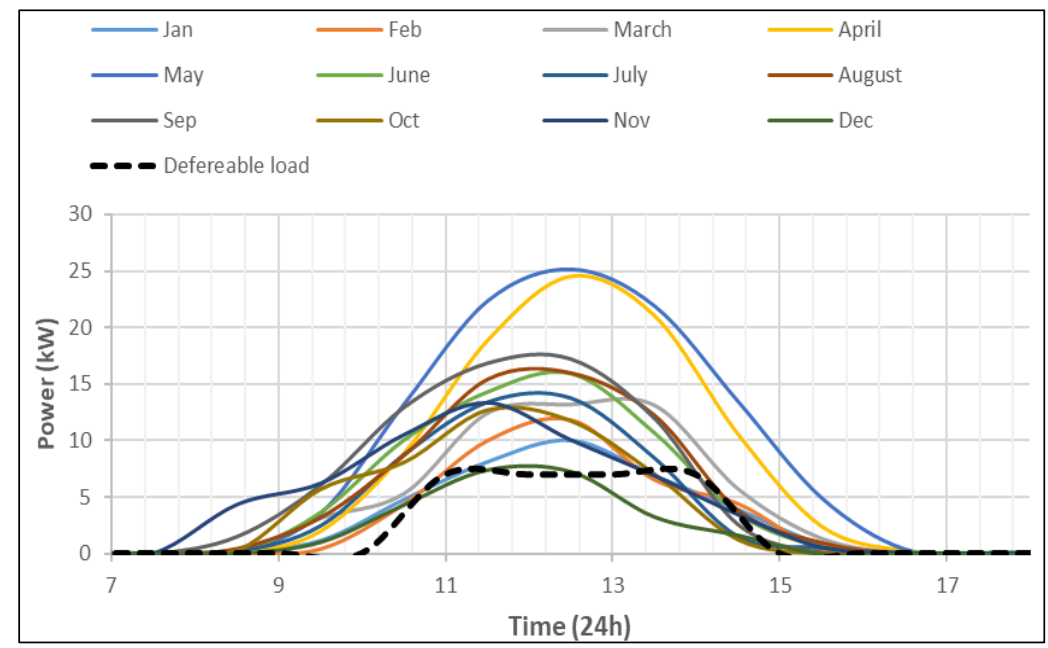

Figure 29. Excess electrical distribution in each month during the day

In order to assess the benefits of utilizing excess energy on the COE, a simulation study is performed using the configuration shown in Figure 30. The deferrable load used to reduce the excess electrical energy is shown in Figure 29. The deferrable load is electric demand that must be served within the time period, but the exact timing is not important. Water pumping and battery charging are normally modeled as deferrable load [39]. The deferrable load profile is selected based on different issues includes the power demand of the water pump, the capacity of the water storage tank, the capacity of the spring, and the water demand for the farmers. Figure 31 shows a comparison study between the simulation results of the PV/BESS/DG with and without excess energy management. The simulation results indicate that adding a deferrable load on the PV/BESS/DG system at the specified profile in Figure 29 reduces the excess energy from $10.6 \%$ to $6.24 \%$. This reduces the levelized COE to USD $0.416 / \mathrm{kWh}$. It is worth noting the energy management procedure followed in this case does not nullify the excess energy.

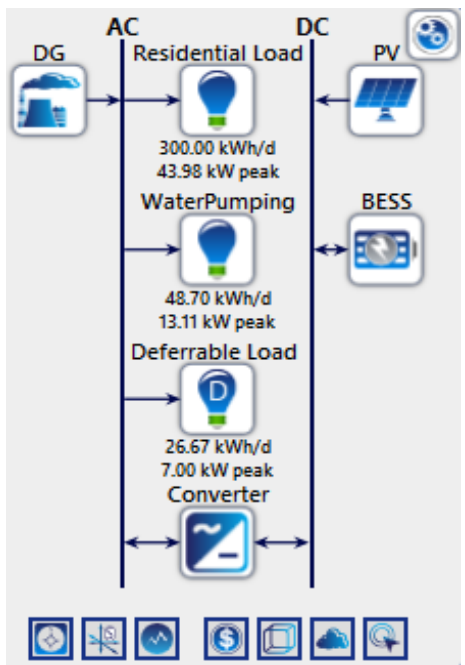

Figure 30. Excess energy management configuration of $\mathrm{PV} / \mathrm{BESS} / \mathrm{DG}$

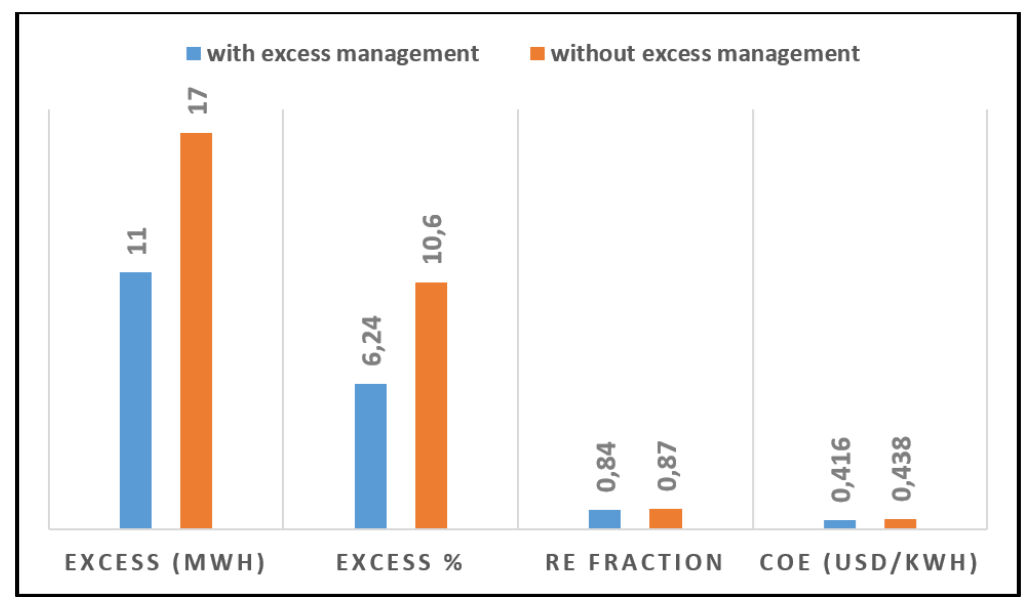

Figure 31. Results of comparison study of PV/BESS/DG configuration with and without excess energy management

\section{CONCLUSION}

The PV system with BESS combined with DG is the most economical hybrid system to electrify the specified load in this study. The COE is USD0.438/kWh. The NPC of the system is US $\$ 645,622$. The capacity of the PV system is $88 \mathrm{~kW}, 144$ batteries of $1900 \mathrm{Ah}$ each and $14 \mathrm{~kW}$ DG. The power system provides the specified residential and water pumping load with almost no interruption to the power supply. The system based on PV and BESS is competitive to PV/BESS/DG option. The COE obtains in this

Optimization with excess electricity management of a PV, energy storage and diesel... (Aysar Yasin) 
configuration is USD $0.521 / \mathrm{kWh}$. The renewable energy fraction is $100 \%$ without a negative impact on the environment. However, this configuration will become more competitive if reduced emissions incentive programs were available. In the future, PENRA's strategic objectives include building and adopting such incentive programs. This option is more competitive if fees are paid for gases emitted from power stations or other facilities.

The study also investigates the feasibility of the hybrid system consisting of a PV system combined with DG. The COE obtained from this system is USD $0.568 / \mathrm{kWh}$. This system is competitive to PV/BESS in terms of the COE. This system doesn't utilize BESS which is considered an advantage. The renewable energy fraction is $57 \%$. The excess electrical energy is about $34 \%$. The study investigates utilizing DG only. In fact, this option is completely not feasible in terms of COE and environmental impacts. The COE obtains in this option is USD $0.666 / \mathrm{kWh}$. The amount of carbon dioxide and monoxide is approximately 130 tons/year and $323 \mathrm{~kg} /$ year, respectively. The study also investigates the option of utilizing DG combined with BESS. The COE obtains from this option USD $0.609 / \mathrm{kWh}$. It has a high environmental impact but less than using DG only. The sensitivity analysis showed that the cost of the PV power system and the price of diesel fuel are the predominant factors in determining the optimum hybrid system and the COE. The effect of MACS on the excess electricity fraction is not significant. The study proposes an energy management procedure to increase the feasibility of utilizing RES. After studying the excess power distribution and studying the local demand of the residents as well as the capacity of the water pump and storage tank, a deferrable load is assumed. The simulation results indicate sensible improvement in the amount of excess power as well as a reduction in COE.

\section{REFERENCES}

[1] PCBS, "Imported energy in Palestine by type of energy and month, 2017," 2017. [Online]. Available: at http://www.pcbs.gov.ps/Portals/_Rainbow/Documents/EnergyImports-2017-4E.html.

[2] P. Palestinian Energy and Environment Research Center, "Country report of Palestine-paving the way for MSP," 2012.

[3] Abdel-Karim Dauda and Mahmoud S. Ismail, "Design of isolated hybrid systems minimizing costs and pollutant emissions," Renewable Energy, vol. 44, pp. 215-224, 2012.

[4] A. Gupta, "Modeling of hybrid energy system," Dissertation, Dept. HRED, Indian Institute of Technology Roorkee, 2010.

[5] S. I. Sulaiman and N. A. Ali, "Performance simulation of the integration of hybrid stand-alone photovoltaic system at Tuba Island," Indonesian Journal of Electrical Engineering and Computer Science, vol. 16, no. 1, pp. 107-115, 2019.

[6] C. Supriya and M. Siddarthan, "Optimization and sizing of a grid-connected hybrid PV-Wind energy system," International Journal of engineering science and technology, vol. 3, no. 5, pp. 4296-4323, 2011.

[7] B. Yassine and A. Boumediene, "Renewable energies evaluation and linking to smart grid," International Journal of Power Electronics and Drive Systems, vol 11, no 1, pp107-118, 2020.

[8] S. Ibim, M. Mustafa, and F. Obite. "Modelling and analysis of a PV/wind/diesel hybrid standalone microgrid for rural electrification in Nigeria," Bulletin of Electrical Engineering and Informatics, vol. 8, no. 4, pp 1468-1477, December 2019.

[9] S. Kumar, G. Shabarish, and Kishore Kannan A., "IoT based wind/solar hybird inverter," International Journal of Advances in Applied Sciences, vol. 5, no. 3, pp 137-140, 2016.

[10] A. S. Azizi, M. F. N. Tajuddin, M. R. Adzman, M. F. Mohammed, and M. A. M. Ramli, "Feasibility analysis of grid connected and islanded operation of a solar PV microgrid system: A case study of Iraq," Energy, vol. 191, 2020.

[11] Gui-Xiong He, Ling Cheng, Jin Xu, Lei Chen, and Wen-Quan Tao, "Optimal configuration of a Wind/PV/Battery hybrid energy system using HOMER software," Chemical engineering transactions, vol. 61, pp. 1507-1512, 2017.

[12] A. Can Duman and Önder Güler, "Techno-economic analysis of off-grid PV/Winf/Fuel cell hybrid system combinations with a comparison of regularly and seasonally occupied households," Sustainable Cities and Society, vol. 42, pp. 107-126, 2018.

[13] C. Li, D. Zhou, H. Wang, Y. Lu, and D. Lie, "Techno-economic performance study of stand-alone wind/diesel/battery hybrid system with different battery technologies in the cold region of china," Energy, vol. 192, 2020.

[14] B. Afif, B. Merabet, A. Benhamou, and A. Chaker, "Standalone hybrid power system using homer software optimal case sizing of ferraguig (North West of Algeria)," International Journal of Applied Power Engineering, vol 8, no. 3, pp 287-298, 2019.

[15] M. Shahzad, A. Zahid, T. Rashid, M. Rehan, M. Ali, and M. Ahmad, "Techno-economic feasibility analysis of a solar-biomass off grid system for electrification of remote rural areas in Pakistan using HOMER software," Renewable Energy, vol. 106, pp. 264-273, 2017.

[16] H. Zahboune, S. Zouggar, G. Krajacic, P. Varbanov, M. Elhafyani, and E. Ziani, "Optimal hybrid renewable energy design in autonomous system using modified electric system cascade analysis and HOMER software," Energy conversion and management, vol. 126, pp. 909-922, 2016.

[17] L. Halabi, S. Mekhilef, L. Olatomiwa and J. Hazelton, "Performance analysis of hybrid PV/diesel/battery system using HOMER: A case study Sabah, Malaysia," Energy conversion and management, vol. 144, pp. 322-339, 2017.

[18] B. Abu-Hijleh, "Use of hybrid PV and wind turbine-grid connected system in a local Emirati home in Dubai-UAE," Energy Procedia, vol. 100, pp. 463-468, 2016. 
[19] M. Deshmukh and A. Singh, "Modeling of energy performance of stand-alone SPV system using HOMER Pro," Energy Procedia, vol. 156, pp. 90-94, 2019.

[20] A. Singh, P. Baredar, and B. Gupta, "Computational simulation and optimization of a solar, fuel cell and biomass hybrid energy system using HOMER Pro software," Procedia Engineering, vol. 127, pp. 743-750, 2015.

[21] A. Rousis, D. Tzelepis, I. Konstantelos, C. Booth, and G. Strbac, "Design of a hybrid AC/DC microgrid using HOMER Pro: case study of an islanded residential application," Inventions, vol. 3, no. 3, pp. 1-14, 2018.

[22] F. Fazelpour, N. Soltani, and M. Rosen, "Economic analysis of standalone hybrid energy systems for application in Tehran, Iran," International journal of hydrogen energy, vol. 41, no. 19, pp. 7732-7743, 2016.

[23] W. Amutha and V. Rajini, "Cost benefit and technical analysis of rural electrification alternatives in southern India using HOMER," Renewable and sustainable energy reviews, vol. 62, pp. 236-246, 2016.

[24] G. Rohani and M. Nour, "Techno-economical analysis of stand-alone hybrid renewable power system for Ras Musherib in United Arab Emirates," Energy, vol. 64, pp. 828-841, 2014.

[25] L. Montouri, M. Alcazar-Ortega, C. Alveraz-Bel, and A. Domijan, "Integration of renewable energy in microgrids coordinated with demand response resources: Economic evaluation of a biomass gasification plant by HOMER simulator," Applied energy, vol. 132, pp. 15-22, 2014.

[26] T. Nacer, A. Hamidat, and O. Nadjemi, "Feasibility study and electric power flow of grid connected Photovoltaic dairy farm in Mitidja (Algeria)," Energy Procedia, vol. 50, pp. 581-588, 2014.

[27] Y. H. L. L. Ma T, "A feasibility study of a stand-alone hybrid solar/wind/battery system for a remote island," Applied energy, vol. 121, pp. 149-158, 2014.

[28] D. E. Babatunde, O. M. Babatunde, M. U. Emezirinwune, I. H. Denwigne, T. E. Okharedia, and O. J. Omodara, "Feasibility analysis of an off-grid photovoltaic-battery energy system for a farm facility." International Journal of Electrical and Computer Engineering, vol. 10, no. 3, pp. 2874-2883, 2020.

[29] P. Kumar, M. Mohanty, and S. Kar. "Techno-economic evaluation of stand-alone hybrid renewable energy system for remote village using HOMER-pro software," International Journal of Applied Power Engineering, vol 6, no. 2, pp 73-88. 2017.

[30] S. G. Fikari, S. G. Sigarchian, and H. R. Chamorro, "Modeling and simulation of an autonomous hybrid power system," 2017 52nd International Universities Power Engineering Conference (UPEC), Heraklion, pp. 1-6, 2017.

[31] Md Shahinur Islama, Ruma Akhter, and Md Ashifur Rahman, "A thorough investigation on hybrid application of biomass gasifier and PV resources to meet energy needs for a northern rural off-grid region of Bangladesh: A potential solution to replicate in rural off-grid areas or not?," Energy, vol. 145, pp 338-355, 2018.

[32] Felix A. Farret and M. Godoy Simões, "Micropower system modeling with HOMER," in Integration of Alternative Sources of Energy, IEEE, pp.379-418, 2006.

[33] The Applied Research Institute-Jerusalem, "Ein el Beida village profile," 2006. [Online]. Available at: http://proxy.arij.org/tubas/static/localities/profiles/98_Profile.pdf. [Accessed 21 Feb 2020].

[34] The Energy Research Centre (ERC)-Nablus, "Meteorological measurements in West Bank/Nablus," An-Najah National University, 2001.

[35] A. M. Yasin, "The impact of dispatchability of parabolic trough CSP Plants over PV power plants in Palestinian territories," International Journal of Photoenergy, vol. 2019, pp. 1-19, 2019.

[36] A. M. Yasin, "Technical and financial assessment of glazed and evacuated tubes solar collectors for domestic water heating application in Palestine," An-Najah Univ. J. Res. (N. Sc.), vol. 31, no. 1, pp. 151-172, 2017.

[37] M. Suri et. al., "Atlas of solar resources, Palestinian territories," Reference No 126-01/2014, 4 August 2014.

[38] M. J. Shawon, L. El Chaar, and L. A. Lamont, "Overview of wind energy and its cost in the Middle East," Sustainable Energy Technologies and Assessments, vol. 2, pp. 1-11, 2013.

[39] HOMER Energy, "HOMER Pro 3.13 user manual, released April 29, 2019," 2019. [Online]. Available: https://www.homerenergy.com/products/pro/docs/index.html. [Accessed: 20 Dec 2019].

\section{BIOGRAPHIES OF AUTHORS}
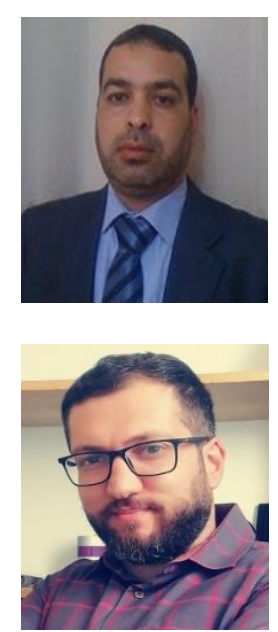

Aysar Yasin is an assistant professor at An-najah National University (ANU), Palestine. He finished his bachelor degree in electrical engineering from ANU in 1999, master degree in clean energy and energy conservation engineering from ANU in 2008, and his $\mathrm{PhD}$ in energy in 2012 from university of Catania, Italy. His main research interests in distributed energy systems based on renewable energy sources mainly PV and wind energy systems with different types of energy storage systems. He is teaching theoretical and applied courses (labs) on solar PV systems and solar thermal systems for undergraduate and graduate students. He works as a local and international consultant in different companies working in the field of RE and EE

Mohammed F. Alsayed is an assistant professor at An-najah National University (ANU), Palestine. He finished his bachelor degree in industrial engineering from ANU at 2005, master degree in clean energy and energy conservation engineering from ANU in 2008, and his $\mathrm{PhD}$ in energy management in 2013 from University of Catania, Italy. He is teaching many undergraduate and graduate courses, including energy management and conservation, sustainability and life cycle assessment, engineering economy, and HVAC. Alsayed research interests include optimization, energy efficiency, sustainability, waste to energy, and life cycle assessment. 